\title{
Ameliorative Effect of Ascorbic Acid and/or Ginseng Extract against Thyroid Gland Toxicity Induced by Potassium Dichromate in Rats
}

\author{
Samar S Ibrahim ${ }^{1}$, Alshaimaa M Said ${ }^{2}$ and Mohamed Aboubakr ${ }^{3 *}$ \\ ${ }^{1}$ Forensic medicine and toxicology Department, Faculty of Veterinary Medicine, Benha University, 13736 Moshtohor, Toukh, Qaliobiya, Egypt \\ ${ }^{2}$ Biochemistry Department, Faculty of Veterinary Medicine, Benha University, 13736 Moshtohor, Toukh, Qaliobiya, Egypt. \\ ${ }^{3 *}$ Pharmacology Department, Faculty of Veterinary Medicine, Benha University, 13736 Moshtohor, Toukh, Qaliobiya, Egypt.
}

Submission: February 12, 2018; Published: March 01, 2018

*Corresponding author: Mohamed Aboubakr, Pharmacology Department, Faculty of Veterinary Medicine, Benha University, 13736 Moshtohor, Toukh, Qaliobiya, Egypt, Email: mohamed.aboubakr@fvtm.bu.edu.eg

\begin{abstract}
The ameliorative effects of ascorbic acid and/or ginseng on the toxicity of chromium on the thyroid gland were reported in rats. Fifty male rats were divided into five groups $(\mathrm{n}=10)$. The 1 st group was received saline; $2^{\text {nd }}$ group received potassium dichromate $(2.5 \mathrm{mg} / \mathrm{kg}) ; 3^{\text {rd }} \mathrm{group}$ received potassium dichromate and ascorbic acid (120 mg/kg); $4^{\text {th }}$ group administrated potassium dichromate and ginseng extract (20 mg/kg) and 5th group administrated potassium dichromate and ascorbic acid and ginseng extract. All groups were administrated orally by stomach tube daily for 4 weeks. A significant increase in serum TSH level at the 2 nd group; whereas it decreased significantly in the $3^{\text {rd }}$ and $4^{\text {th }}$ groups on comparison with the control group. The level of $\mathrm{T}_{3}, \mathrm{~T}_{4}, \mathrm{FT}_{3}$ and FT $\mathrm{F}_{4}$ concentrations showed a significant decrease in $2^{\text {nd }}$ group; while in $3^{\text {rd }}$ and $4^{\text {th }}$ groups a significant increase on its level when compared with control group. Moreover, rats received potassium dichromate showed degeneration and necrosis of the thyroid follicles associated with vacuolation of other epithelial lining. The immune expression of Bcl ${ }_{2}$ in thyrocytes cytoplasm was reported. So, the structural changes in thyroid follicular cells induced by potassium dichromate were partially improvement by ascorbic acid and ginseng supplementation.

Keywords: Potassium dichromate; Thyroid gland; Antiapopatic marker Bcl2; Rats
\end{abstract}

\section{Introduction}

Chromium has a variety of toxic effects which represent a hazard for human and animal's health [1]. Chromium is required for metabolism of protein, carbohydrate and fat that exists in various oxidation states, trivalent (Cr III) and hexavalent (Cr VI) forms are predominant and $\mathrm{Cr}$ (VI) is broadly used in industrial chemicals [2]. Hexavalent chromium usually bound with oxygen forming strong oxidizing agent causing allergic dermatitis as well as toxic and carcinogenic effects in humans and animals [3]. Inside the cell, $\mathrm{Cr}$ VI was reduced to $\mathrm{Cr}$ III, resulting in reactive oxygen species formation together with oxidative tissue damage and a cascade of cellular events [4]. Occupational exposure to $\mathrm{Cr}$ VI is found among approximately half a million industrial workers around the world. Also, water contaminated with hexavalent chromium is a global problem, as it is the major route of chromium exposure for the general population [5]. Potassium dichromate $\left(\mathrm{K}_{2} \mathrm{Cr}_{2} \mathrm{O}_{7}\right)$ is an inorganic soluble hexavalent chromium compound that is widely used in several industries [6].
Antioxidants were identified to protect tissues of animal from $\mathrm{Cr}$ (VI) which induced cellular injury [7]. Vitamin C (Ascorbic acid) is an essential micronutrient performs important metabolic functions, a potent water soluble antioxidant able to scavenge a variety of free radicals and oxidative molecules because of its reversible conversion to dehydroascorbic acid [8]. It also involved in the metabolism of tyrosine and act as cholesterol metabolism regulator, prevent oxidative renal and brain damage induced by stress and secure the body tissues against toxic effects of heavy metals by efficiently metabolizing these toxicants. Ascorbic acid can reduce chromium-induced toxicity on liver and kidney [9]. In traditional medicine, Ginseng is a general tonic by increasing vitality, health, and longevity of older persons [10].

It's aqueous extracts composed of a mixture of ginsenosides, trace minerals, glycosides, different complex carbohydrates, protein, peptides and amino acids and of different pharmacological effects as anti-carcinogenic, anti-diabetic 
and anti-inflammatory, cardiovascular and neuro protection [11]. It has antioxidant properties and used in maintaining oxidative status [12]. The aim of this study was to investigate the ameliorative effect of ascorbic acid and/or ginseng against $\mathrm{K}_{2} \mathrm{Cr}_{2} \mathrm{O}_{7}$-induced thyroid gland toxicity in rats.

\section{Materials and methods}

\section{Chemicals}

Potassium Dichromate $\left(\mathrm{K}_{2} \mathrm{Cr}_{2} \mathrm{O}_{7}\right)$, ascorbic acid and ginseng were supplied by El-Nasr pharmaceutical chemicals, Egypt. Potassium dichromate is an orange red crystalline powder odorless with bitter metallic taste, soluble in water.

\section{Animals}

This study was carried out on fifty adult male albino rats weighing between 200 to $250 \mathrm{~g}$ from Veterinary Serum and Vaccine Research Institute, Abbasia, Cairo, Egypt. All rats were housed at room temperature for 2 weeks before the start of the experiment. A commercial balanced diet and water ad-libitum were provided. Ethical Committee of Faculty of Veterinary Medicine, Benha University approved this study.

\section{Experimental Design}

Rats were randomly divided into five groups 10 rats each one.

a) $\quad 1^{\text {st }}$ group: received saline and kept as control.

b) $2^{\text {nd }}$ group: received potassium dichromate with dose $2.5 \mathrm{mg} / \mathrm{kg}$ BW (1/10 LD50) [13].

c) $3^{\text {rd }}$ group: received potassium dichromate at the same dose and ascorbic acid $120 \mathrm{mg} / \mathrm{kg}$ [14].

d) $4^{\text {th }}$ group: administrated potassium dichromate at the same dose and ginseng extract $20 \mathrm{mg} / \mathrm{kg}$ [15].

e) $5^{\text {th }}$ group: administrated potassium dichromate and ascorbic acid and ginseng extract as the same above doses.

All groups were administrated orally by stomach tube daily for 4 weeks and kept under observation all over the duration of experiment. At the end of experiment, blood samples were collected through direct heart puncture in sterile test tubes without anticoagulant for separation of serum which kept

\section{Results}

\section{Biochemical results}

Table1: Effect of ascorbic acid and/or ginseng extract administration on serum thyroid profile in normal and $\mathrm{K}_{2} \mathrm{Cr}_{2} \mathrm{O}_{7}$ intoxicated rats ( $\mathrm{n}=10$ ).

\begin{tabular}{|c|c|c|c|c|c|}
\hline Groups & $\mathbf{F T}_{4}(\mathbf{n g} / \mathbf{d l})$ & $\mathbf{F T}_{3}(\mathbf{p g} / \mathbf{d l})$ & $\mathbf{T}_{4}(\mathbf{U g} / \mathbf{d l})$ & $\mathbf{T}_{3}(\mathbf{n g} / \mathbf{d l})$ & $\mathbf{T S H}(\boldsymbol{\mu l U} / \mathbf{m l})$ \\
\hline $1^{\text {st }}$ group & $1.85 \pm 0.02^{\mathrm{a}}$ & $4.89 \pm 0.08^{\mathrm{a}}$ & $9.26 \pm 0.18^{\mathrm{a}}$ & $112.3 \pm 2.08^{\mathrm{a}}$ & $0.048 \pm 0.003^{\mathrm{c}}$ \\
\hline $2^{\text {nd }}$ group & $1.24 \pm 0.02^{\mathrm{e}}$ & $3.70 \pm 0.03^{\mathrm{c}}$ & $4.48 \pm 0.16^{\mathrm{d}}$ & $81.2 \pm 1.6^{\mathrm{d}}$ & $0.116 \pm 0.009^{\mathrm{a}}$ \\
\hline $3^{\text {rd }}$ group & $1.60 \pm 0.02^{\mathrm{c}}$ & $4.19 \pm 0.03^{\mathrm{b}}$ & $5.14 \pm 0.10^{\mathrm{c}}$ & $106.20 \pm 1.85^{\mathrm{b}}$ & $0.066 \pm 0.005^{\mathrm{b}}$ \\
\hline $4^{\text {th }}$ group & $1.35 \pm 0.02^{\mathrm{d}}$ & $4.17 \pm 0.19^{\mathrm{b}}$ & $4.88 \pm 0.24^{\mathrm{c}}$ & $90.80 \pm 1.93^{\mathrm{c}}$ & $0.078 \pm 0.003^{\mathrm{b}}$ \\
\hline $5^{\text {th }}$ group & $1.73 \pm 0.03^{\mathrm{b}}$ & $4.25 \pm 0.16^{\mathrm{b}}$ & $7.34 \pm 0.21^{\mathrm{b}}$ & $107.40 \pm 2.73^{\mathrm{ab}}$ & $0.064 \pm 0.004 \mathrm{~b}^{\mathrm{c}}$ \\
\hline
\end{tabular}

Mean with different litters at the same column differ significant $(P<0.05)$.

at $-20^{\circ} \mathrm{C}$ untill biochemical analysis and then all rats were euthanized. For immune histo chemical and Histopathological studies, thyroid gland was collected and fixed in $10 \%$ buffered neutral formalin solution.

\section{Biochemical analysis}

The blood was drawn directly from the left ventricle through cardiac puncture to obtain the serum for determination of TSH (Thyroid stimulating hormone) [16], T3 (Triiodotyrosine) [17], T4 (Thyroxin) [18], FT3 (Free triiodotyrosin) and FT4 (Free tetraiodotyrosine) was determined in serum [19]. Histopathological examination and Immunohistochemical staining for detection of $\mathrm{Bcl} 2$ protein (antiapopatic marker): The thyroid glands were collected surgically [20], as a small reddish mass for histopathological examination and immunehistochemical methods for detection of apoptosis using BCL2 immune expression. Immunohistochemical reaction was performed using avidin biotin peroxidase technique [21,22]. The primary antibody was a rabbit monoclonal antibody (Sigma Laboratories). Tissue sections were deparaffinized and rehydrated. Slides were incubated in hydrogen peroxide (10\%) for 10-15 min.

Antigen retrieval was done by immersing the sections in a pre-heated citrate buffer solution $(\mathrm{pH} 6)$ and maintaining heat in a microwave at $2 \mathrm{~W}$ for $10-20 \mathrm{~min}$. Sections were left to cool for $20 \mathrm{~min}$ at room temperature. Slides were washed in buffer $(0.05 \%$ sodium azide) for 2 times. Monoclonal antibody Bcl2-Ab-1 (Ms-123-R7) was applied. Slides were washed in buffer $(0.05 \%$ sodium azide) for 4 times. Biotinylated goat anti-polyvalent was applied. Slides were incubated at room temperature for $10 \mathrm{~min}$. Slides were washed in buffer $(0.05 \%$ sodium azide) for 4 times. Chromogenic substrate was applied (diaminobenzidine) DAB and incubated until desired reaction was achieved. Mayer's haematoxylin was used as a counter stain. The Bcl2 cytoplasmic site of reaction was stained brown and nuclei stained blue. To prepare negative control sections, same method used without adding primary antibody [23].

\section{Statistically analysis}

Statistically the data were analyzed by using SPSS for windows (Version 18). Using (ANOVA) test and Duncan test for evaluating the significance of differences between groups. 
The presented data revealed a significant increase $(\mathrm{P}<0.05)$ in serum TSH on the $2^{\text {nd }}$ group, non significant increase in its concentration in serum of $5^{\text {th }}$ group while in 3 rd and 4 th group showed significant decrease of TSH serum concentration when compared with control group. Regarding to T3, T4, FT3 and FT4 level in serum of rats in $2^{\text {nd }}$ group showed; significant decrease in compared to control group(1st group), while $3^{\text {rd }}, 4$ th group showed significant increase in T3, T4, FT3 and FT4 levels in serum in comparison with 2 nd group. While 5 th group showed non-significant decrease in T3 level in serum in compared with 1st group, but it exhibited significant increase in T4 and FT4 concentrations in serum when compared to 3 rd and 4 th group (Table 1).

\section{Histopathological study}

Regarding to thyroid glands of 1st group showing normal thyroid follicles lined with cuboidal epithelium and filled with homogenous colloid fluid (Figure 1A) while thyroid glands of 2nd group showing degeneration and necrosis of the thyroid follicles associated with vacuolation of other the epithelial lining of the others (Figure 1B). While in treated groups (3rd, 4 th and 5th group) showed different degree of vacuolation on thyroid follicles as in 3rd group showing vacuolation of the lining epithelium of the thyroid follicles (Figure 1C). Thyroid follicles of 4th group showing moderate degree of vacuolation of lining epithelium of the thyroid follicles (Figure 1D), and thyroid follicle of 5th group showing mild vacuolation of the lining epithelium of the thyroid follicles (Figure 1E).

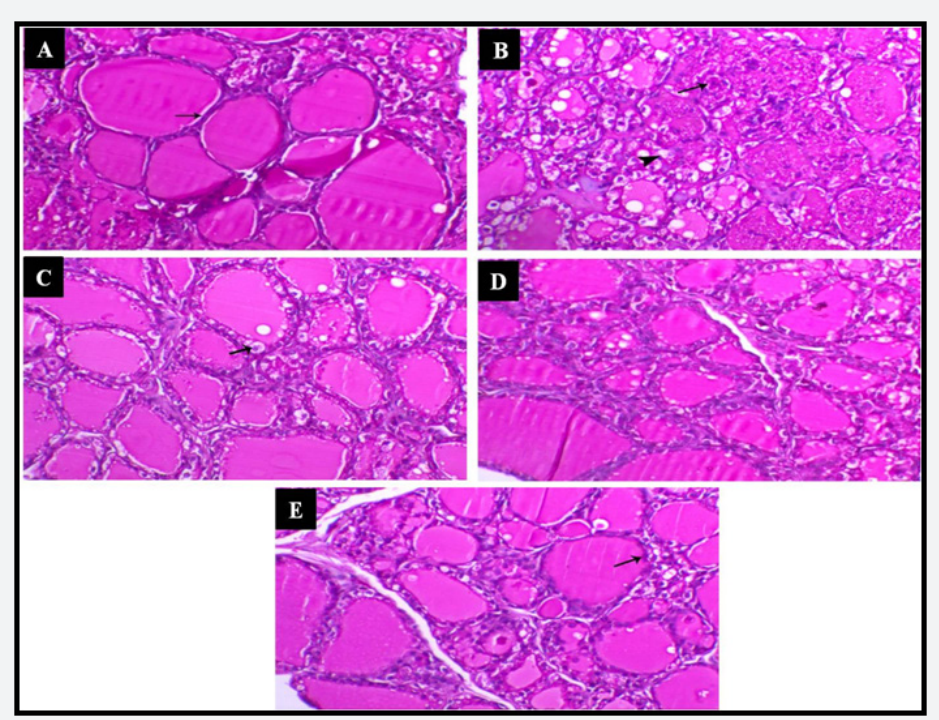

Figure 1: Effect of ascorbic acid and/or ginseng extract administration on histopathological structure of thyroid gland in normal and $\mathrm{K}_{2} \mathrm{Cr}_{2} \mathrm{O}_{7}$ intoxicated male albino rats. Stain (H\&E), X200.

A: group 1 (control); B: group $2\left(\mathrm{~K}_{2} \mathrm{Cr}_{2} \mathrm{O}_{7}\right)$; C: group $3\left(\mathrm{~K}_{2} \mathrm{Cr}_{2} \mathrm{O}_{7}+\right.$ ascorbic acid); D: group $4\left(\mathrm{~K}_{2} \mathrm{Cr}_{2} \mathrm{O}_{7}+\right.$ ginseng); $\mathrm{E}$ : group $5\left(\mathrm{~K}_{2} \mathrm{Cr}_{2} \mathrm{O}_{7}+\right.$ ascorbic acid + ginseng).

\section{Immuno histo chemical results}

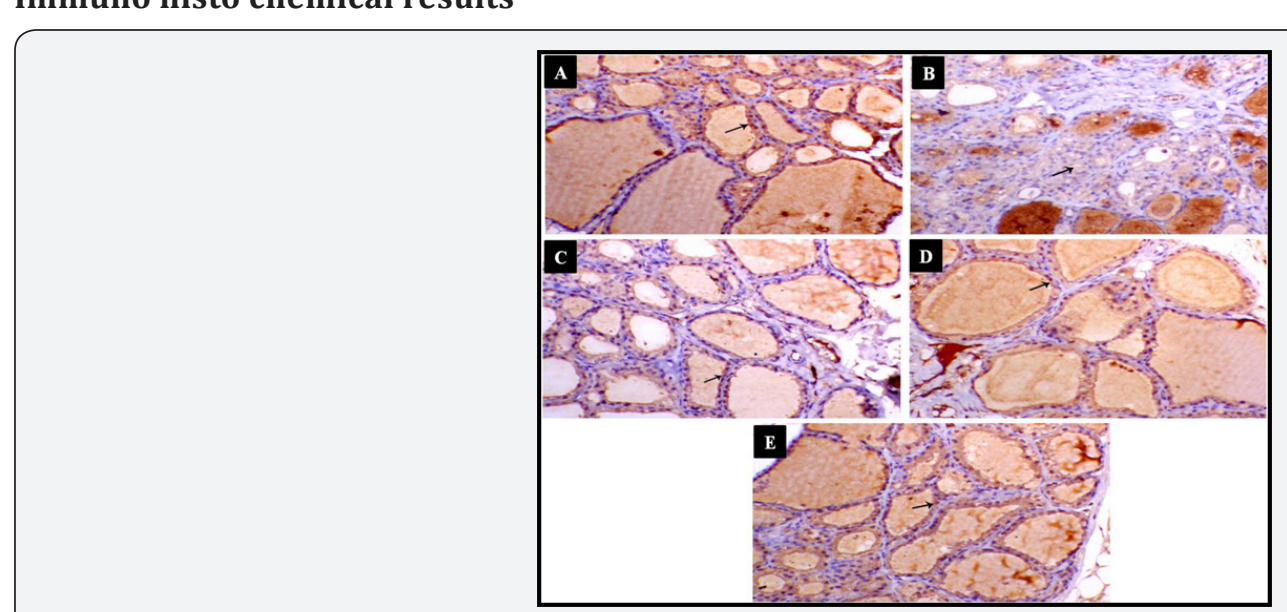

Figure 2: $\mathrm{Bcl}_{2} \mathrm{IHC}$ expression in thyroid gland from ascorbic acid and/or ginseng extract and $\mathrm{K}_{2} \mathrm{Cr}_{2} \mathrm{O}_{7}$-treated groups. $\mathrm{Bcl}_{2}$ immunostaining, X200.

A: group 1 (control); B: group $2\left(\mathrm{~K}_{2} \mathrm{Cr}_{2} \mathrm{O}_{7}\right)$; C: group $3\left(\mathrm{~K}_{2} \mathrm{Cr}_{2} \mathrm{O}_{7}+\right.$ ascorbic acid); D: group $4\left(\mathrm{~K}_{2} \mathrm{Cr}_{2} \mathrm{O}_{7}+\right.$ ginseng); $\mathrm{E}$ : group $5\left(\mathrm{~K}_{2} \mathrm{Cr}_{2} \mathrm{O}_{7}+\right.$ ascorbic acid + ginseng). 
The Thyroid glands of rats in 2nd groups showed negative cytoplasmic BCL2 immune expression within the lining epithelium of the follicles compared with thyroid gland of rats in 1st group showed strong cytoplasmic BCL2 immune expression within the lining epithelium of the follicles (Figures 2A \& 2B). Although the thyroid glands of rats in 3rd and 4th group show BCL2 immunoexpression within the lining epithelium of the follicles (Figures 2C \& 2D). Moreover, in 5th group showed marked BCL2 immunoexpression within the lining epithelium of the follicles compared with 1st and 2nd group (Figure 2E).

\section{Discussion}

There is a close relationship between workers health and the amounts of industrial effluents provoked by industries manufacturing chromium containing materials [24]. This study shown effects of potassium dichromate on the thyroid gland which appeared in the form of a state of hypothyroidism as indicated by a significant increase in TSH concentration and significant decrease in T3, T4, FT3 and FT4 concentrations in serum of $\mathrm{K}_{2} \mathrm{Cr}_{2} \mathrm{O}_{7}$ intoxicated rats when compared to control group. These results came in accordance with those reported after exposure to hexavalent chromium resulted in sever hypothyroid state as indicated by decreased FT4 and FT3 serum concentrations and increased TSH serum concentration [14]. Levels of T3 and T4 in serum are indicators of the thyroid function and any change in their levels reflects disturbance in their synthesis and/or secretion, as well as disorders in the extra thyroidal metabolism [25].

The recorded increase in serum TSH of $\mathrm{K}_{2} \mathrm{Cr}_{2} \mathrm{O}_{7}$ intoxicated rats might be a body attempt to stimulate the thyroid gland to increase the synthesis and secretion of $\mathrm{T} 3$ and $\mathrm{T} 4$ to compensate the apparent deficit in the system [26]. Moreover, The low T4 concentration in serum of the $\mathrm{K}_{2} \mathrm{Cr}_{2} \mathrm{O}_{7}$ intoxicated rats may stimulated the hypothalamic neurons to secrete thyrotrophin releasing hormone (TRH), which increased stimulation of TSH synthesis [27]. Also, decreased levels of thyroid hormones and hyperplasia of the thyroid indicated that the chromium administration induced suppression of the thyroid hormone synthesis and release, which in turn stimulated the pituitary to secrete more TSH because of the negative feedback mechanism [28].

The recorded decrease FT4 concentration has been attributed to the active combination between chromium and globulins present in the animal body and it is possible that it enhances the synthesis of thyroglobulin; however, at the same time it hinders the process of proteolysis of thyroglobulin and consequent decrease of serum FT4 concentration [29]. Chromium caused thyroid toxicity through enhancing cellular oxidative stress and decreasing the antioxidants activity [30]. This was confirmed by histological changes in the form of marked degeneration and necrosis of the thyroid follicles associated with vaculation of the epithelial lining in the $\mathrm{K}_{2} \mathrm{Cr}_{2} \mathrm{O}_{7}$ intoxicated rats. Similar results after Cr VI administration, which caused hypertrophy of the anterior pituitary cells, and increase the number of follicles in the thyroid gland with disorganized structure and large interfollicular spaces that appeared among the follicles, dissolution of the connective tissue [31].

Also, chromium administration induced collapsed and disintegrated follicles, colloid retraction or absorption, hyperplasia, alteration of the cellular architecture and damaged or reduced number of cell organelles [28]. The observed degeneration and necrosis of the thyroid follicles could be attributed to the oxidative stress induced by $\mathrm{Cr}$ (VI) that results in oxidative deterioration of biological macromolecules. $\mathrm{Cr}$ (VI) enhanced reactive oxygen species production such as superoxide ion, hydroxyl radicals and hydrogen peroxide which result in increased lipid peroxidation, DNA damage, membrane damage and altered gene expression and apoptosis [32]. Furthermore, TSH is responsible for the morphological appearance of thyroid follicles and the synthesis and secretion of thyroid hormones. The engulfment of colloid material from the follicular lumen into the apical cytoplasm of thyrocytes, in the form of membranebound colloid droplets is one of the early responses of TSHstimulated thyroid follicular cells [33].

In the present study the electron microscope investigations support the cellular histological changes observed by light microscope. Thyroid glands of $\mathrm{K}_{2} \mathrm{Cr}_{2} \mathrm{O}_{7}$ intoxicated rats showed marked decrease in BCL2 expression within the lining epithelium of the follicles. These results were came in accordance with those reported by [34] who reported that hexavalent $\mathrm{Cr}$ induced DNA fragmentation, increased apoptosis, increased cytochrome $\mathrm{C}$ release from the mitochondria to cytosol, down regulated antiapoptotic BCL2 and other mediators; upregulated proapoptotic. Also, negative cytoplasmic BCL2 immunoexpression in the majority of follicular cells in Potassium dichromate intoxicated rats [33]. The soluble $\mathrm{Cr}$ (VI) is metabolized within cells by reductive agents as ascorbic acid, glutathione and cysteine producing a diverse range of genetic lesions. Some forms of Cr damage present physical barriers to DNA replication/ transcription and promote a terminal cell fate such as apoptosis or terminal growth arrest. Other DNA lesions are potentially premutagenic and lead to DNA damage and cell cycle arrest [35].

Antioxidants protect cells and tissues from destructive effects of ROS and other free radicals. Vitamin $\mathrm{C}$ and/or ginseng administration in $\mathrm{K}_{2} \mathrm{Cr}_{2} \mathrm{O}_{7}$ intoxicated rats induced significant decrease in TSH and significant increase in T3, T4, FT3 and FT4 concentrations in comparison with $\mathrm{K}_{2} \mathrm{Cr}_{2} \mathrm{O}_{7}$ intoxicated group. The normalization of the TSH concentration and improvement in $\mathrm{T} 4$ and $\mathrm{T} 3$ concentration in group pretreated with vitamin $\mathrm{C}$ as a protective measure against chlorpyrifos and lead [26]. Moreover, ascorbic acid leads to a significant increase in the level of the T3 and T4 and a significant decrease in the serum TSH compared with potassium dichromate intoxicated rats [33]. On cellular level the degeneration and necrosis of the thyroid follicles were attenuated on administration of ascorbic acid and/or ginseng mild to moderate degree of vaculation in the lining epithelium of the follicles. 
Also, the thyroid glands of $\mathrm{K}_{2} \mathrm{Cr}_{2} \mathrm{O}_{7}$ intoxicated rats administered vitamin $\mathrm{C}$ or ginseng show BCL2 expression within the lining epithelium of the follicles. Moreover, $\mathrm{K}_{2} \mathrm{Cr}_{2} \mathrm{O}_{7}$ intoxicated rats thyroid administered ascorbic acid and ginseng showed marked BCL2 immunostaining within the lining epithelium of the follicles. Vitamin C administration to potassium dichromate treated group showed some improvement in the structure of thyroid gland [33]. The ability of ascorbic acid and/ or ginseng to remove free radicals and oxidative molecules produced by reduction of $\mathrm{Cr}$ (VI) to $\mathrm{Cr}$ (III) as vitamin C improve thyroid health through diminishing the oxidative stress on the gland either by foreign toxins and harmful free radicals or from the reactive oxygen species produced during thyroid hormones syntheses [36]. Furthermore, improvement in thyroid gland function and structure probably underlines the role of oxidative stress in thyroid dysfunction induced by administration of potassium dichromate and administration of vitamin $\mathrm{C}$ and ginseng protected the thyroid gland from oxidative damage and helped in restoring its synthetic function [26].

Ascorbic acid influenced chromium toxicity either by acting as a reducing agent, lowering chromium persistence or by its role as an antioxidant, decreasing the formation of intracellular superoxide anion and hydrogen peroxide and also it acts by reducing free radicals formed during reduction of $\mathrm{Cr}(\mathrm{VI})$ to Cr(III) [37]. Ginseng extract inhibit lipid Peroxidation through transition metal chelation and to diminish oxidative DNA damage caused by UV exposure [38,39]. Therefore, ginseng acts through its ability to increase cellular levels of vitamins $\mathrm{E}$ and $\mathrm{C}$ as well as catalase activity and or directly scavenge toxic hydroxyl radicals in cells and protect cells from Cr (VI) toxicity [40].

\section{Conclusions}

The present study indicates that co-administration of vitamin $\mathrm{C}$ and ginseng proved to have better ameliorative role against potassium dichromate toxic effect on thyroid gland. It is recommended to provide antioxidants as vitamin $\mathrm{C}$ and/ or ginseng as ameliorative agent against chromium toxicity in people who are susceptible for continuous exposure.

\section{Acknowledgement}

We would like to express our thank Prof. Dr. Hossam Attia, Department of Histology and Cytology, Faculty of Veterinary Medicine, Benha University, Egypt, for his histopathological and immunohistochemical assistance.

\section{References}

1. S Kawanishi, Y Hiraku, M Murata, S Oikawa (2002) The role of metals in site-specific DNA damage with reference to carcinogenesis. Free Radic Biol Med 32(9): 822-832.

2. WT Cefalu, FB Hu (2004) Role of chromium in human health and in diabetes. Diabetes care 27(11): 2741-2751.

3. AM Farag, T May, GD Marty, M Easton, DD Harper, et al. (2006) The effect of chronic chromium exposure on the health of Chinook salmon (Oncorhynchus tshawytscha). Aquat Toxicol 76(3-4): 246-257.
4. AK Patlolla, C Barnes, D Hackett, PB Tchounwou (2009) Potassium dichromate induced cytotoxicity, genotoxicity and oxidative stress in human liver carcinoma (HepG2) cells. Int J Environ Res Public Health 6(2): 643-653.

5. SI Nudler, FA Quinteros, EA Miler, JP Cabilla, SA et al. (2009) Chromium VI administration induces oxidative stress in hypothalamus and anterior pituitary gland from male rats. Toxicol Lett 185(3): 187-192.

6. NA Arivarasu, S Fatima, R Mahmood (2008) Oral administration of potassium dichromate inhibits brush border membrane enzymes and alters anti-oxidant status of rat intestine. Arch Toxicol 82(12): 951958.

7. K Salnikow, A Zhitkovich (2008) Genetic and Epigenetic Mechanisms in Metal Carcinogenesis and Cocarcinogenesis: Nickel, Arsenic and Chromium. Chem Res Toxicol 21: 28-44.

8. P Murugesan, T Muthusamy, K Balasubramanian, J Arunakaran (2005) Studies on the protective role of vitamin C and E against polychlorinated biphenyl (Aroclor 1254) induced oxidative damage in Leydig cells. Free Radic Res 39(11): 1259-1272.

9. A Pechova, L Pavlata (2007) Chromium as an essential nutrient: a review. Veterinarini Medicina 51(1): 1-18.

10. YK Kim, Q Guo, L Packer (2002) Free radical scavenging activity of red ginseng aqueous extracts. Toxicology 172(2): 149-156.

11. CH Jung, HM Seog, IW Choi, HD Choi, HY Cho, et al. (2005) Effects of wild ginseng (Panax ginseng C.A. Meyer) leaves on lipid peroxidation levels and antioxidant enzyme activities in streptozotocin diabetic rats. J Ethnopharmacol 98(3): 245-250.

12. HF Chang, YH Lin, CC Chu, SJ Wu, YH Tsai, et al. (2007) Protective effects of Ginkgo biloba, Panax ginseng, and Schizandra chinensis extract on liver injury in rats. Am J Chin Med 35(6): 995-1009.

13.JG Patel, DV Joshi, BJ Patel, SH Raval, PS Lambade, et al. (2016) Potassium Dichromate induced genotoxicity and oxidative stress in Wistar rats (Rattus norvegicus). Indian J Vet Pathol 40(1): 42-46.

14. IZ Qureshi, T Mahmood (2010) Prospective role of ascorbic acid (vitamin $\mathrm{C}$ ) in attenuating hexavalent chromium-induced functional and cellular damage in rat thyroid. Toxicol Ind Health 26(6): 349-359.

15. AM Hassan, SH bdel Aziem, AA El-Nekeety, MA Abdel-Wahhab (2015) Panax ginseng extract modulates oxidative stress, DNA fragmentation and up-regulate gene expression in rats sub chronically treated with aflatoxin B1 and fumonisin B1. Cytotechnology 67(5): 861-871.

16. M Soos, SJ Taylor, T Gard, K Siddle (1984) A rapid, sensitive twosite immunometric assay for TSH using monoclonal antibodies: Investigation of factors affecting optimization. J Immunol Methods 73(2): 237-249.

17. WH Walker (1977) An Approach to Immunoassay. Clin Chem 23: 384402.

18. GB Wisdom (1976) Enzyme-immunoassay. Clin Chem 22(8): 12431255.

19. LR Witherspoon, SE Shuler, MM Garcia, LA Zollinger (1980) An assessment of methods for the estimation of free thyroxine. J Nucl Med 21(6): 529-539.

20. SNH Hadie, H Abdul Manan, S Abdulla (2013) Thyroid gland resection in euthanized rat A practical guide. Int Med J 20(1): 1-4.

21. JA Kiernan (1999) Histological and histochemical methods: theory and practice. $3^{\text {rd }}$ edn. Shock 12: 479.

22. F Lin, J Prichard (2015) Handbook of Practical Immunohistochemistry. Springer, New York, USA.

23. A Huang, PD Fone, R Gandour-Edwards, RW White, RK Low, et al. (1999) Immunohistochemical analysis of BCL-2 protein expression in renal cell carcinoma. J Urol 162(2): 610-613. 
24. JM Antonini, AB Lewis, JR Roberts, DA Whaley (2003) Pulmonary effects of welding fumes: review of worker and experimental animal studies. Am J Ind Med 43(4): 350-360.

25. RM Rolland (2000) A review of chemically-induced alterations in thyroid and vitamin-A status from field studies of wildlife and fish. J Wildl Dis 36(4): 615-635.

26. SF Ambali, C Orieji, WO Abubakar, M Shittu, MU Kawu, et al. (2011) Ameliorative effect of vitamin $\mathrm{C}$ on alterations in thyroid hormones concentrations induced by subchronic coadministration of chlorpyrifos and lead in wistar rats. J Thyroid.

27.SS Nussey, SA Whitehead (2001) Endocrinology: An Integrated Approach. Bios Scientific Publishers Oxford, UK.

28. T Mahmood, IZ Qureshi, MJ Iqbal (2010) Histopathological and biochemical changes in rat thyroid following acute exposure to hexavalent chromium. Histol Histopathol 25(11): 1355-1370.

29. AT Goncharov, AS Ametov (1977) Thyroid gland morphological and functional indices in the experimental action of chromium. Probl Endokrinol 23(6): 59-61.

30. CM Thompson, DM Proctor, LC Haws, CD Hebert, SD Grimes, et al. (2011) Investigation of the mode of action underlying the tumorigenic response induced in B6C3F1 mice exposed orally to hexavalent chromium. Toxicol Sci 123(1): 58-70.

31. T Mahmood, IZ Qureshi, MS Nadeem, MA Khan (2008) Hexavalent chromium toxicity in pituitary and thyroid glands. Pakistan J Zool 40(2): 91-97.

32. R Shrivastava, RK Upreti, PK Seth, UC Chaturvedi (2002) Effects of chromium on the immune system. FEMS Immunol Med Microbiol 34(1): 1-7.
33. RH ElBakry, SM Tawfik (2014) Histological study of the effect of potassium dichromate on the thyroid follicular cells of adult male albino rat and the possible protective role of ascorbic acid (vitamin C). J Microscopy Ultrastructure 2(3): 137-150.

34. SK Banu, JA Stanley, J Lee, SD Stephen, JA Arosh, et al. (2011) Hexavalent chromium-induced apoptosis of granulosa cells involves selective subcellular translocation of Bcl-2 members, ERK1/2 and p53. Toxicol Appl Pharmacol 251(3): 253-266.

35. FA Quinteros, LI Machiavelli, EA Miler, JP Cabilla, BH Duvilanski, et al. (2008) Mechanisms of chromium (VI)-induced apoptosis in anterior pituitary cells. Toxicology 249(2-3): 109-115.

36. K Peepre, U Deshpandey, PS Choudhary (2014) Role of antioxidants on thyroid hormones in wister rats. Int J Sci Res 3(1): 35-38.

37. B Poljsak, Z Gazdag, S Jenko Brinovec, S Fujs, M Pesti, et al. (2005) Prooxidative vs antioxidative properties of ascorbic acid in chromium(VI)induced damage: an in vivo and in vitro approach. J Appl Toxicol 25(6): 535-548.

38. DD Kitts, AN Wijewickreme, C Hu (2000) Antioxidant properties of a North American ginseng extract. Mol Cell Biochem 203(1-2): 1-10.

39. YS Keum, KK Park, JM Lee, KS Chun, JH Park, et al. (2000) Antioxidant and anti-tumor promoting activities of the methanol extract of heatprocessed ginseng. Cancer lett 150(1): 41-48.

40. H Akram, F Ghaderi Pakdel, A Ahmadi, S Zare (2012) Beneficial effects of american ginseng on epididymal sperm analyses in cyclophosphamide treated aats. Cell J 14(2): 116-121.

\section{Your next submission with Juniper Publishers will reach you the below assets}

- Quality Editorial service

- Swift Peer Review

- Reprints availability

- E-prints Service

- Manuscript Podcast for convenient understanding

- Global attainment for your research

- Manuscript accessibility in different formats

( Pdf, E-pub, Full Text, Audio)

- Unceasing customer service

Track the below URL for one-step submission

https://juniperpublishers.com/online-submission.php 